\title{
PENERAPAN MODEL PROBLEM BASED LEARNING MENGGUNAKAN LEMBAR KERJA SISWA UNTUK MENINGKATKAN KEMAMPUAN PEMECAHAN MASALAH BELAJAR KIMIA SISWA KELAS X DI SMA NEGERI 1 ANGKOLA BARAT
}

\author{
Jennita Rambe ${ }^{1)}$, Abubakar'), Wiwik Novitasari' ${ }^{2)}$ \\ ${ }^{1)}$ Program Studi Pendidikan Kimia, FKIP Universitas Muhammadiyah Tapanuli Selatan \\ ${ }^{2)}$ Program Studi Pendidikan Matematika, FKIP Universitas Muhammadiyah Tapanuli Selatan \\ email: jennitarambe01@gmail.com
}

\begin{abstract}
The research is the research action class. The model used is a model of problem based learning. As for the data collection technique used is the test, observation, interview and question form and data gathering tool used is the test sheet, sheets of observation, the now closed and the format of the interview. The data will be analyzed with descriptive analysis method i.e., first make a list of the frequency of the first. Based on the data analysis done is obtained that the application of the model of problem based learning using worksheets students committed researchers is to improve student learning and activity the performance of teachers.
\end{abstract}

Keyword: Problem Based Learning, research action class, the student's activities

\begin{abstract}
Abstrak
Penelitian ini adalah penelitian tindakan kelas. Model yang digunakan adalah model problem based learning. Adapun teknik pengumpulan data yang digunakan adalah tes, observasi, angket dan wawancara dan alat pengumpulan data yang digunakan adalah lembar tes, lembar observasi, angket tertutup dan format wawancara. Data akan dianalisis dengan metode deskriptif analisis yaitu terlebih dahulu membuat daftar frekuensi terlebih dahulu. Berdasarkan analisis data yang dilakukan diperoleh bahwa penerapan model problem based learning menggunakan lembar kerja siswa yang dilakukan peneliti adalah untuk meningkatkan aktivitas belajar siswa dan aktivitas kinerja guru.
\end{abstract}

Kata Kunci : Problem Based Learning, penelitian tindakan kelas, aktifitas siswa

\section{PENDAHULUAN}

Mata pelajaran kimia merupakan salah satu cabang ilmu pengetahuan alam yaitu perpaduan antara mata pelajaran berupa sistem hafalan, perhitungan, dan belajar konsep yang harus dipahami serta memberikan inovasi agar siswa mampu memecahkan masalah dan mengkaitkannya dengan kehidupan sehari-hari. Penting bagi siswa untuk meningkatkan pemecahan masalah belajar dan berusaha sendiri untuk mencari solusi pemecahannya akan menghasilkan pengetahuan yang benar bermakna. sebab dengan usaha sendiri untuk mencari pemecahan masalah secara mandiri akan memberikan pengalaman dan makna tersendiri bagi pesera didik. (Dwi dan Muchlis, 2016). 
Sejalan dengan itu, dalam memecahkan masalah yang lumayan rumit anak anak akan sanggup bila mereka terbiasa dibimbing menggunakan istilah yang akrab 
dan konkrit bagi mereka, walalupun seringkali juga gagal dan juga kesulitan dalam menjawab soal. Dalam proses pembelajaran, siswa harus sering diajak untuk memecahkan masalah yang sesuai dengan usia dan pengalaman mereka. Jika anak dibiasakan memecahkan masalah, maka guru atau orang tua telah membangun gudang untuk memecahkan masalah - masalah berikutnya. (Aunurrahman, 2009)

Pemecahan masalah yaitu suatu pendekatan dimana langkah - langkahnya sampai penyelesaian akhir lebih bersifat kuantitatif dan spesifik. Apabila pemecahan yang diharapkan tidak berjalan sebagaimana yang diinginkan, berarti terjadi kesalahan dalam tahap awal sehingga peserta didik harus kembali berpikir dari awal untuk mendapatkan pemahaman menyeluruh mengenai masalah yang sedang dihadapi. (Widodo, 2014)

Menurut Nuryanto dkk. (2015) PBL (problem based learning) adalah serangkaian aktivitas pembelajaran yang memusatkan kepada proses penyelesaian masalah yang dihadapi secara ilmiah dan PBL tidak mengharapkan siswa hanya sekadar mendengarkan, mencatat, kemudian menghafal materi, tapi dengan PBL diharapkan siswa aktif berpikir, mencari informasi, mengolah data, mempresentasikan solusinya, dan menyimpulkan. Langkah - langkah PBL Secara umum terdiri dari lima tahap yaitu: (1) Mengorientasikan siswa pada suatu masalah, (2) mengorganisasikan siswa untuk meneliti, (3) membantu investigasi siswa secara mandiri maupun kelompok, (4) mempresentasikan hasil dan mengembangkannya, (5) menganalisis dan mengevaluasi proses pemecahan masalah.

Pembelajaran berbasis masalah (problem based learning) selanjutnya yang disingkat dengan PBL, merupakan model pembelajaran inovatif yang dapat yang dapat memberikan kondisi belajar aktif kepada siswa. PBL adalah suatu model pembelajaran yang melibatkan siswa untuk memecahkan masalah melalui tahap tahap metode ilmiah sehingga siswa dapat mempelajari pengetahuan yang berhubungan dengan masalah tersebut dan sekaligus memiliki keterampilan. (Ngalimun, 2012) sejalan dengan itu Menurut (Refriwati, 2015) Pembelajaran berbasis masalah yaitu belajar mengajar di dalam kelas dengan proses siswa terlebih dahulu diminta mengamati suatu fenomena. Tugas guru hanyalah mengarahkan siswa untuk bertanya, merangsang untuk berfikir kritis dalam memecahkan masalah yang ada. membuktikan asumsi, dan mendengarkan perspektif yang berbeda diantara mereka. Kemudian siswa diminta untuk mencatat permasalahannya.

\section{METODE}

Jenis Penelitian ini adalah PTK (penelitian tindakan kelas), dimana tindakan yang dilakukan terhadap sekelompok siswa dalam waktu yang sama dan pelajaran yang sama dan guru yang sama dengan tujuan tertentu untuk mencapai suatu harapan yang diinginkan. (Wardoyo, 2013), Penelitian ini dilaksanakan di kelas X MS 1 SMA Negeri 1 Angkola Barat, waktu penelitian ini dilaksanakan pada tanggal 07 April 2018 s/d 04 Mei 2018. Subjek dalam penelitian ini adalah siswa kelas X MS 1 SMA Angkola Barat yang terdiri dari 34 siswa, terdiri dari 13 siswa laki-laki dan 21 siswa perempuan. Siklus penelitian ini dianggap berhasil jika kriteria ketuntasan sudah mencapai $75 \%$. Prosedur penelitian tindakan kelas ini terdiri dari 2 siklus, setiap siklus terdiri dari dua kali pertemuan melalui empat tahapan

\section{Analisis Data}

Analisis data tes kemampuan pemecahan masalah belajar kimia siswa kelas x pada materi reaksi redoks. Setelah data tes kemampuan pemecahan masalah belajar kimia 
siswa melalui penerapan model problem based learning menggunakan lembar kerja siswa diperoleh, kemudian data yang diperoleh disajikan dalam tabel distribusi frekuensi.

Untuk menghitung frekuensi dapat dilakukan dengan langkah-langkah sebagai berikut:

1. Menentukan rentang

Rentang $=$ data terbesar - data terkecil

2. Menentukan banyak kelas interval dengan menggunakan rumus:

Banyak kelas $=1+3,3(\log n)$

3. Menentukan panjang kelas interval

$$
P=\frac{\text { rentang }}{\text { banyak kelas }}
$$

4. Untuk mengetahui Mean terlebih dahulu menggunakan langkah-langkah sebagai berikut :

- Menentukan mean dengan (mean terkaan) yang biasanya diambil pada kelas interval yang mempunyai kelas terbesar. Besarnya MT (Mean Terkaan) adalah jumlah batas-batas interval dibagi 2 .

- Menentukan deviasi dugaan (diberi symbol d), dimana pada kelas interval yang mempunyai frekuensi terbesar diberi harga 0 . Kalau lebih dari 0 diberiharga (+) dankurang dari 0 diberiharga (-).

- Menghitung mean sebenarnya dengan rumus :

- Mean terkaan $=\frac{\text { batas } \text { kelas }}{2}$

- Mean $=\mathrm{MT}+\mathrm{i}\left(\frac{\sum f d}{N}\right)^{2}$

5. Standar Deviasi

Standar deviasi banyak digunakan dalam analisis statistik deskriptif.

\section{HASIL DAN PEMBAHASAN}

\section{A. Hasil Penelitian}

Penelitian ini berpedoman dari tindakan awal untuk mengetahui kemampuan awal siswa dan seberapa besar tingkat kemampuan pemecahan masalah belajar kimia siswa di kelas X MS - 1 SMA N 1 Angkola Barat terhadap pelajaran kimia khususnya pada materi reaksi redoks.

\section{Hasil Penelitian Tindakan Kelas Siklus I}

Siklus I merupakan pembelajaran dengan materi reaksi redoks dengan menerapkan model problem based learning menggunakan lembar kerja siswa. Siklus I dilaksanakan dua pertemuan. Pertemuan pertama 2 jam pelajaran $(2 \times 45$ menit $)$ pertemuan kedua 3 jam pelajaran (3 x 45 menit) di SMA Negeri 1 Angkola Barat tahun pelajaran 2017 - 2018, hasil dari tahap siklus I diuraikan sebagai berikut:

\section{a. Perencanaan (Planning)}

Perencanaan ini dilaksanakan pada hari selasa 6 Maret 2018 pukul 08.00 Wib di ruang guru. Peneliti dan guru mendiskusikan rancangan tindakan yang akan dilakukan dalam proses penelitian, kemudian disepakati pelaksanaan tindakan pada siklus I pada pertemuan pertama dilaksanakan pada hari rabu 7 maret 2018 (2 jam pelajaran).

Pada kesempatan tersebut peneliti dengan guru mendiskusikan hal - hal sebagai berikut yaitu: Peneliti menjelaskan perencaaan, RPP, instrumen penelitian berupa test dan nontest, angket, wawancara yang dipersiapkan peneliti dan guru 
menyetujuinya, guru memberikan idenya dalam merangsang aktivitas belajar kimia siswa pada materi reaksi redoks agar meningkat yaitu dengan membuat buah apel sebagai stimulus dan mengaitkannya dengan reaksi redoks, kemudian guru dan siswa merumuskan indikator pencapaian tujuan (IPK), LKS dan terakhir guru dan penelilti Menentukan jadwal penelitian.

Adapun tahap perencanaan tindakan I meliputi

- Peneliti dan guru merancang skenario pembelajaran dengan model problem based learning menggunakan lembar kerja siswa sesuai dengan rencana pelaksanaan pembelajaran (RPP) yang sudah dirancang.

- Peneliti menyusun hasil instrumen tes dan hasil observasi aktivitas siswa dan aktivitas kinerja guru.

\section{b. Pelaksanaan (Action)}

Pertemuan pertama dilaksanakan pada hari rabu 7 Maret 2018 (08.45 10.00) selama 2 jam pelajaran ( 2 x 45 menit) di ruang kelas X MS -1 SMA Negeri 1 Angkola Barat. Sedangkan Pertemuan kedua dilaksanakan pada hari rabu 14 Maret 2018 (08.00 - 10.00). selama 3 jam pelajaran (3 x 45 menit) diruang kelas X MS - 1 SMA Negeri 1 Angkola Barat. Adapun pelaksanaan tindakan kelas disesuaikan dengan perencanaan yang terstruktur di atas. Guru bertindak sebagai pemimpin berjalannya proses belajar mengajar dan tim observer bertindak sebagai pengamat dalam mengamati jalannya pembelajaran.

\section{c. Hasil Observasi}

- Hasil Observasi Aktivitas Belajar Siswa. Hasil aktivitas belajar siswa di siklus I dapat disimpulkan bahwa aktivitas siswa masih rendah yaitu dengan persentase $47 \%$ yaitu belum mencapai indikator keberhasilan yaitu $75 \%$. perlu dilanjutkan ke siklus II.

- Hasil Observasi Aktivitas Kinerja Guru. Hasil aktivitas guru di siklus I masih rendah yaitu $58 \%$ belum mencapai indikator keberhasilan yaitu 75\% Maka peneliti melanjutkan penelitian ini ke siklus II.

\section{d. Hasil Evaluasi dan Refleksi Siklus I}

\section{Hasil Evaluasi Siklus I}

Berdasarkan evaluasi siklus I, penilaian terhadap tes hasil kemampuan pemecahan masalah belajar kimia siswa pada siklus I. Jumlah siswa yang tuntas pada siklus I yaitu 24 orang dengan persentase sebesar $70.58 \%<75 \%$ sebagai indikator keberhasilan. Dengan demikian hasil tes pemecahan masalah belajar kimia siswa pada siklus I masih rendah dan perlu dilanjutkan ke siklus II. Nilai tes kemampuan pemecahan masalah belajar kimia siswa dapat digambarkan dalam grafik sebagai berikut:

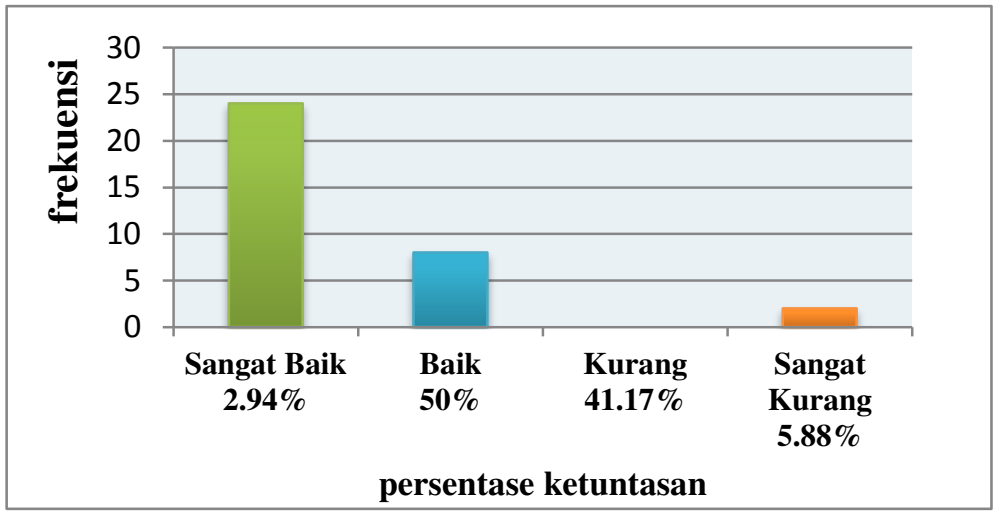

Gambar 1. Grafik Nilai Pemecahan Masalah Belajar Kimia Siswa Siklus I 
Pada gambar 1 dapat disimpulkan bahwa jumlah siswa yang memperoleh kualifikasi nilai sangat baik dengan persentase $2.94 \%$ berjumlah 1 siswa, kualifikasi nilai baik dengan persentase $50 \%$ berjumlah 17 siswa, kualifikasi nilai kurang dengan persentase $41.17 \%$ berjumlah 14 siswa dan kualifikasi nilai sangat kurang dengan persentase $5.88 \%$ berjumlah 2 siswa.

\section{Hasil Refleksi Siklus I}

Setelah melakukan observasi terhadap aktivitas belajar siswa dan kinerja guru pada siklus I diperoleh hasil refleksi sebagai berikut:

\section{a. Kelebihan}

- Dengan memberikan buah apel sebagai stimulus dapat merangsang aktivitas belajar kimia siswa dan mendapat respon yang baik dari siswa.

- beberapa siswa sudah mulai berani menjawab pertanyaan dan stimulus yang diberikan guru.

\section{b. Kekurangan}

- Pengelolaan kelas belum baik, sehingga banyak siswa yang ribut.

- Siswa yang masih belum terbiasa dengan penerapan model problem based learning menggunakan lembar kerja

- Penggunaan waktu yang kurang efisien.

- Siswa yang masih kurang peduli untuk mengikuti pelajaran.

- $\quad$ Siswa yang aktif masih diakomodasi oleh siswa yang pintar

Beberapa hal yang harus diperbaiki pada siklus II adalah sebagai berikut:

- Guru memperbaiki penyampaian materi redoks dengan cara guru lebih mengikut sertakan siswa dalam memecahkan suatu masalah.

- menggunakan waktu secara efektif.

- Memotivasi siswa untuk meningkatkan kemampuan pemecahan masalah belajar kimia siswa.

\section{Hasil Penelitian Tindakan Kelas Siklus II}

Perencanaan siklus II dilaksanakan dua pertemuan. Pertemuan pertama 3 jam pelajaran ( 3 x 45 menit) pertemuan kedua 1 jam pelajaran ( 1 x 45 menit) di SMA Negeri 1 Angkola Barat tahun pelajaran 2017 - 2018, hasil dari tahap siklus II diuraikan sebagai berikut:

\section{a. Perencanaan (Planning)}

Tindakan siklus II pada pertemuan pertama direncanakan pada 28 Maret 2018 pukul (08.00 - 10.00) di kelas X MS - 1 tiga jam mata pelajaran (3 45 menit). Adapun kegiatan yang dilakukan pada tahap ini adalah sebagai berikut, Pada kesempatan tersebut peneliti belajar dari kesalahan dan berusaha memperbaiki kesalahan pada siklus I adapun perencanaan untuk memperbaiki siklus I yaitu:

\section{b. Pelaksanaan (Action)}

Tindakan kedua pertemuan pertama dilaksanakan pada hari rabu 28 April 2018 (08.00 - 10.00) selam 3 jam mata pelajaran (3 x 45 menit) di ruang kelas X SMA Negeri 1 Angkola Barat. Sedangkan tindakan kedua pada siklus II dilaksanakan pada tanggal 4 Mei 2018 (10.00 - 11.00). selama 1 jam mata pelajaran $(1 \mathrm{x} 45$ menit $) \mathrm{di}$ luar sekolah adapun tujuan pada pertemuan kedua ini untuk mewawancarai guru mengenai pendapat guru mengenai penerapan model problem based learning menggunakan lembar kerja siswa. Adapun pelaksanaan tindakan kelas disesuaikan dengan perencanaan yang terstruktur di atas, Guru bertindak sebagai pemimpin berjalannya pembelajaran dan tim observer bertindak sebagai pengamat untuk 
mengamati jalannya proses belajar - mengajar, guru memberikan tes kemampuan pemecahan masalah belajar kimia siswa.

\section{c. Hasil Observasi}

- Hasil Observasi Aktivitas Belajar Siswa. Hasil observasi aktivitas siswa di siklus II dapat disimpulkan bahwa aktivitas siswa sudah mencapai indikator keberhasilan yaitu dengan persentase $85 \%$ yaitu sudah mencapai indikator keberhasilan $75 \%$.

- Hasil Observasi Aktivitas Kinerja Guru. Hasil observasi aktivitas guru dalam proses belajar - mengajar pada siklus II sudah mencapai indikator keberhasilan yaitu $86 \%$ dan sudah melampaui indikator keberhasilan.

\section{d. Hasil Evaluasi dan Refleksi Siklus II}

\section{Hasil Evaluasi Siklus II}

Jumlah siswa yang tuntas pada siklus II yaitu 30 orang atau $88.23 \%>75 \%$. Sehingga dari data tersebut dapat disimpulkan bahwa siklus II sudah memenuhi indikator keberhasilan siswa yaitu melncapai $75 \%$. Dengan demikian hasil tes pemecahan masalah belajar kimia siswa pada siklus II sudah melampaui indikator keberhasilan, Nilai tes pemecahan masalah belajar kimia siswa dapat digambarkan dalam gambar 2.

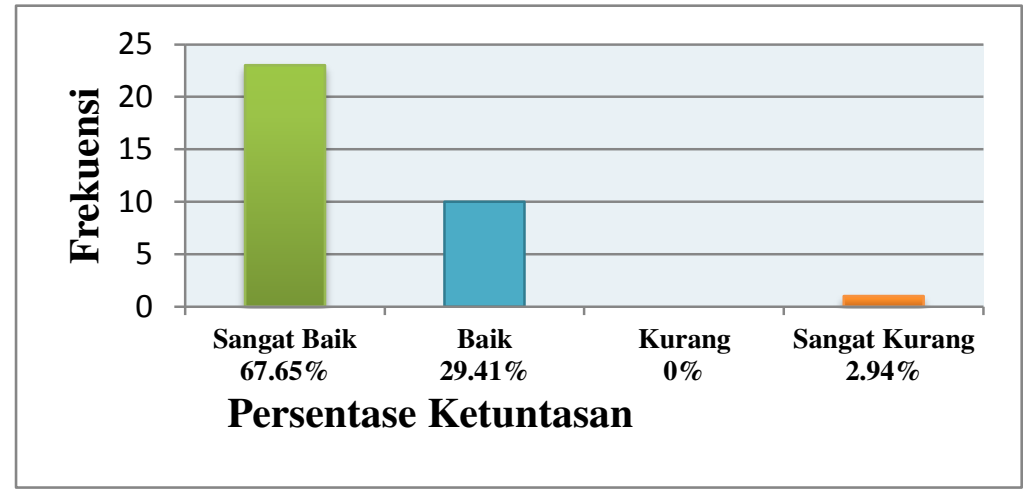

\section{Gambar 2. Grafik Nilai Kemampuan Pemecahan Masalah Belajar Kimia Siswa Siklus II}

Pada gambar 2 dapat disimpulkan bahwa jumlah siswa yang memperoleh kualifikasi nilai sangat baik dengan persentase $67.65 \%$ berjumlah 23 siswa, kualifikasi nilai baik dengan persentaase $29.41 \%$ berjumlah 10 siswa, kualifikasi nilai kurang dengan persentase $0 \%$ berjumlah 0 siswa dan kualifikasi nilai sangat kurang persentase $2.94 \%$ berjumlah 1 siswa.

\section{Hasil Refleksi Siklus II}

Setelah melakukan observasi terhadap aktivitas belajar siswa dan kinerja guru pada siklus II diperoleh hasil refleksi sebagai berikut:

\section{a. Kelebihan}

- Aktivitas kinerja guru meningkatkan pada siklus II ini dibuktikan dengan persentase nilai $82 \%$ pertemuan 1 dan $88 \%$ pada pertemuan 2 jadi mencapai rata - rata $85 \%$ dengan kualifikasi sangat baik.

- Aktivitas belajar kimia siswa meningkat dimana pertemuan I dengan nilai $84 \%$ dan pada pertemuan ke 2 mencapai nilai $86 \%$ jadi mencapai rata - rata $85 \%$ degan kualifikasi sangat baik. 
- Instrumen tes belajar siswa sudah mencapai bahkan melampaui indikator keberhasilan yaitu terbukti dari rata - rata pencapaian 77.94 dan ketuntasan siswa mencapai $88.23 \%$

\section{b. Kekurangan}

Masih ada 1 siswa yang masih sangat kurang dan 3 siswa yang masih kurang dalam kemampuan memecahkan masalah belajar kimia siswa.

\section{B. Hasil Pembahasan Penelitian}

Menurut Makmur (2015: 13-14) Setelah diberikan tindakan kelas dengan menggunakan pembelajaran Base Method telah terjadi peningkatan kreativitas dan motivasi siswa. Peningkatan hasil observasi kreativitas yaitu jika pada tes awal memperoleh rata - rata sebesar $28,91 \%$, Pada siklus I memperoleh rata - rata sebesar 56,082 \% dan pada siklus II memperoleh rata - rata sebesar 76,5 \% siswa. Sedangkan peningkatan hasil observasi motivasi yaitu jika pada tes awal memperoleh rata - rata sebesar $47 \%$ pada siklus I meperoleh rata - rata sebesar $108,9 \%$ yaitu siswa / wi kelas IX B SMP N 10 Padangsidimpuan tidak memiliki motivasi dalam belajar adalah 25 siswa .

Begitu juga dengan penelitian yang saya laksanakan terjadi peningkatan kemampuan pemecahan masalah belajar kimia siswa setelah diberikan tindakan kelas berupa penerapan model problem based learning menggunakan lembar kerja siswa. Peningkatan kemampuan pemecahan masalah belajar kimia siswa yaitu jika pada tes awal memperoleh rata - rata sebesar 2.034 dengan persentase ketuntaasan sebesar $26.47 \%$, pada siklus I memperoleh rata - rata 64.85 dengan persentase ketuntasan siswa $70.58 \%$ dan pada siklus II memperoleh mean sebesar 77.94 dengan persentase ketuntasan siswa $88.23 \%$. Dan persentase hasil observasi aktivitas belajar kimia siswa dari siklus I yaitu $47 \%$ dan terjadi peningkatan di siklus II yaitu $85 \%$ dan persentase hasil observasi aktivitas kinerja guru dari siklus I yaitu $56 \%$ dan terjadi peningkatan di siklus II yaitu $85 \%$.

Hasil Peningkatan kemampuan pemecahan masalah belajar kimia siswa pada siklus I masih rendah yaitu jumlah siswa yang tuntas pada siklus I yaitu 24 orang dengan persentase sebesar $70.58 \%<75 \%$ sebagai indikator keberhasilan. Dengan demikian perlu dilanjutkan ke siklus II, dan hasil tes kemampaun pemecahan masalah belajar kimia siswa pada siklus II yaitu jumlah siswa yang tuntas meningkat yaitu 30 orang dengan persentase sebesar $88.23 \%>75 \%$. Sehingga dari data tersebut dapat disimpulkan bahwa siklus II sudah memenuhi indikator keberhasilan siswa yaitu mencapai $75 \%$. Dengan demikian hasil tes pemecahan masalah belajar kimia siswa pada siklus II sudah melampaui indikator keberhasilan. Peningkatannya dapat di lihat pada gambar 3 .

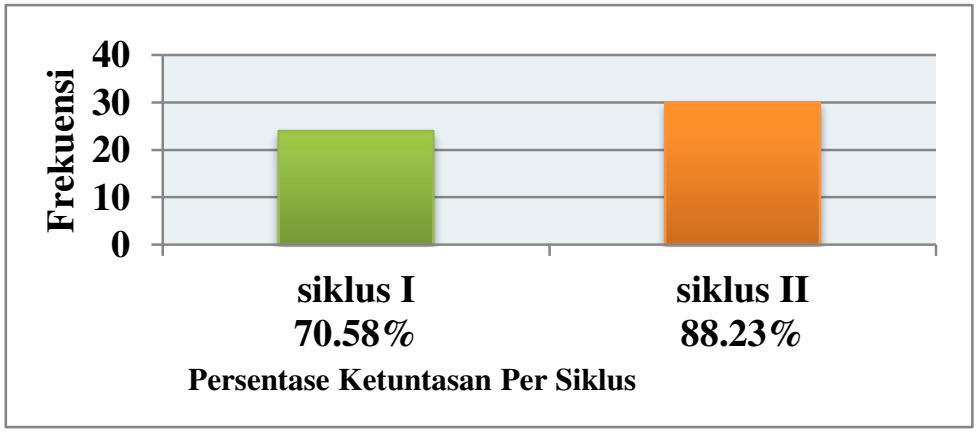

Gambar 3. Grafik Peningkatan Kemampuan Pemecahan Masalah Belajar Kimia Siswa Siklus I dan Siklus II 


\section{1) Peningkatan Aktivitas Kinerja Guru Siklus I dan Siklus II Hasil peningkatan Aktivitas Belajar Siswa}

Hasil lembar observasi pemecahan masalah belajar siswa di siklus I dapat disimpulkan bahwa aktivitas siswa masih rendah yaitu dengan persentase $47 \%$ yaitu belum mencapai indikator keberhasilan $75 \%$. maka pembelajaran dilanjutkan pada siklus II dan di siklus II dapat disimpulkan bahwa aktivitas siswa sudah mencapai indikator keberhasilan yaitu dengan persentase $85 \%$ yaitu sudah mencapai indikator keberhasilan 75\%, hal ini dapat dilihat pada gambar 4.

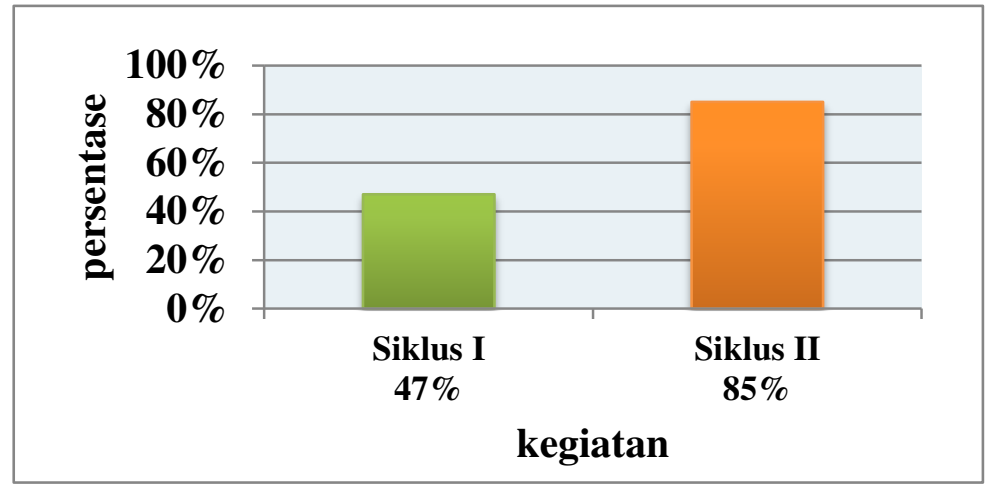

Gambar 4. Grafik Rata - Rata Aktivitas Belajar Kimia Siswa Dengan Model Problem Based Learning Menggunakan Lembar Kerja Siswa

\section{2) Peningkatan Aktivitas Kinerja Guru Siklus I dan Siklus II}

Hasil lembar observasi aktivitas guru dalam proses belajar - mengajar pada siklus I masih rendah yaitu dengan persentase sebesar 58\% yaitu lebih rendah dari 75\% (sebagai indikator keberhasilan). Maka pembelajaran dilanjutkan pada siklus II, dan hasil lembar observasi aktivitas guru dalam proses belajar - mengajar pada siklus II sudah mencapai indikator keberhasilan yaitu dengan persentase sebesar 86\%. Penningkatan hasil observasi aktivitas kinerja guru dapat dilihat pada gambar 5.

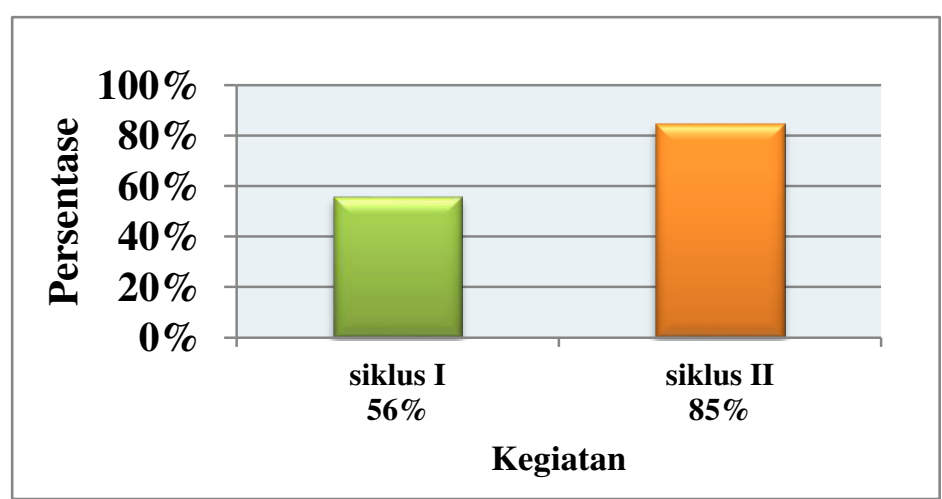

Gambar 5. Grafik Rata - Rata Aktivitas Kinerja Guru Dengan Model Problem Based Learning Menggunakan Lembar Kerja Siswa

\section{3) Hasil Jawaban Angket Siswa}

Hasil jawaban angket siswa mengenai model problem based learning menggunakan lembar kerja siswa yaitu siswa yang tertarik dan senang dengan penerapan model problem based learning menggunakan lembar kerja siswa hal ini 
dapat dilihat dari jawaban angket yang diberikan peneliti yaitu dengan nilai persentase mencapai $80.94 \%$ dengan kualifikasi baik.

\section{4) Hasil Jawaban Wawancara Guru}

Hasil jawaban wawancara guru mengenai model problem based learning menggunakan lembar kerja yaitu Guru merasa tertarik dan terbantu dengan adanya penerapan model problem based learning menggunakan lembar kerja karena guru merasa mudah dalam mengarahkan siswa.

\section{KESIMPULAN}

Penerapan model problem based learning menggunakan lembar kerja siswa dapat meningkatkan aktivitas belajar siswa kelas X MS 1 di SMA Negeri 1 Angkola Barat. Hal ini dapat dilihat dari hasil lembar observasi aktivitas siswa dalam pembelajaran pada siklus I diperoleh rata - rata persentase sebesar $47 \%$ dan meningkat pada siklus II dengan persentase sebesar $85 \%$, jadi terjadi peningkatan sebesar 38\%. Penerapan model problem based learning menggunakan lembar kerja siswa dapat meningkatkan aktivitas kinerja guru hal ini dapat dilihat dari hasil lembar observasi kinerja guru dalam pembelajaran pada siklus I diperoleh rata - rata persentase sebesar $56 \%$ dan meningkat pada siklus II dengan persentase sebesar $85 \%$, terjadi penningkatan yaitu sebesar $29 \%$. Penerapan model problem based learning menggunakan lembar kerja siswa dapat meningkatkan kemampuan pemecahan masalah belajar kimia siswa di kelas X MS 1 SMA Negeri 1 Angkola Barat. Hal ini dapat ditunjukkan dengan hasil kemampuan pemecahan masalah belajar kimia siswa yaitu diperoleh persentase sebesar $70,58 \%$ pada siklus I sedangkan pada siklus II diperoleh persentase sebesar 88,23\%, jadi terjadi peningkatan yaitu sebesar $17,65 \%$.

\section{DAFTAR PUSTAKA}

Aunurrahman. 2009. Belajar dan Pembelajaran. Pontianak: Alfabeta.

Dwi, W.Y. dan Muchlis. (2016). Penerapan Model Problem Based Learning (Pbl) Pada Materi Pokok Larutan Elektrolit dan Nonelektrolit Untuk Melatihkan Kemampuan Pemecahan Masalah Kelas X SMA Negeri 7 Kediri. Unesa Journal of Chemical Education.5.543.

Makmur, A. (2015). Efektifitas Penggunaan Metode Base Method Dalam Meningkatkan Kreativitas Dan Motivasi Belajar Matematika Siswa SMP N 10 Padangsidimpuan. Jurnal EduTech. 1. 13-14.

Ngalimun. 2012. Strategi dan Model Pembelajaran. Banjarmasin: Aswaja Pressindo.

Nuryanto, B. Utami, dan A. Nugroho. (2015). Penerapan Model Pembelajaran Problem Based Learning (Pbl) Dilengkapi Macromedia Flash Untuk Meningkatkan Kemampuan Berpikir Kritis Dan Prestasi Belajar Siswa Pada Materi Pokok Termokimia Kelas XI Siswa SMA Negeri 2 Karanganyar Tahun Pelajaran 2014/2015. Jurnal Pendidikan Kimia (JPK) Universitas Sebelas Maret. 4. 88-90.

Refriwati. (2015). Peningkatan Motivasi Belajar Siswa Dengan Pendekatan Problem Based Learning Pada Pelajaran Kimia Kelas XI Semester 1 SMK N. 1 Bukit Sundi Kecamatan Bukit Sundi Kabupaten Solok. Jurnal Educatio.1. 37-38.

Wardoyo, S.M. 2013. Penelitian Tindakan Kelas. Purbalingga: Graha Ilmu. 
EKSAKTA : Jurnal Penelitian dan Pembelajaran MIPA

Volume 4 Nomor 1 Tahun 2019

Widodo, W. (2014). Problem Solving, Creativity dan Decision Making Dalam Pembelajaran Matematika. Jurnal Eduma. 3. 3-4. 